http://jmscr.igmpublication.org/home/ ISSN (e)-2347-176x ISSN (p) 2455-0450

crossref DOI: https://dx.doi.org/10.18535/jmscr/v8i1.109

\title{
Morbidity and Mortality Profile of Newborns Admitted to the Neonatal Intensive Care Unit of a Tertiary Care Teaching Hospital of Assam
}

\author{
Authors \\ Anupama Deka', Bidyut Bhusan Nath ${ }^{2}$, Anjana T Nair ${ }^{3 *}$ \\ Department of Pediatrics, Silchar Medical College and Hospital, Silchar, Assam, \\ *Corresponding Author \\ Anjana T Nair \\ Department of Pediatrics, Silchar Medical College and Hospital, Silchar, Assam, India
}

\begin{abstract}
Introduction: India contributes to one-fifth of global live births and more than a quarter of neonatal deaths ${ }^{[1]}$. Neonatal mortality is one of the very important indicators, which reflect a country's development. It is of utmost importance to analyse the spectrum of neonatal diseases and the causes of mortality, which in turn will help in formulating strategies for control of neonatal mortality.

Objective: To study the morbidity and mortality profile of neonates admitted in Neonatal Intensive Care Unit (NICU).

Methodology: A retrospective observational study was done in the Neonatal Intensive Care Unit (NICU) to identify the main causes of neonatal morbidity and mortality of admitted neonates over a period of three years from January 2016 to December 2018.

Results: A total of 11,654 neonates were admitted in the NICU during the study period, $60.5 \%$ were in the Inborn and 39.5\% were in the Outborn. $47.7 \%$ of total admissions in our NICU were LBW. The major causes of admission to NICU were observed to be jaundice, RDS, sepsis, Birth asphyxia and Meconium aspiration syndrome. NICU mortality during the study period was found to be $12.37 \%$. Birth asphyxia, sepsis, RDS and MAS were found to be the main contributors of mortality in our NICU.

Conclusion: This study identifies Birth asphyxia as the most important cause of mortality. Outcomes of this study can be utilized in planning and modifying existing health care services for improved care of the newborn.
\end{abstract}

Keywords: NICU, Morbidity, Mortality, Birth asphyxia.

\section{Introduction}

The neonatal period carries the highest risk of mortality per day than any other period during the childhood $^{[1]}$. Each year, about 2.5 million newborns die before they are 4 weeks old according to 2018 data of UNICEF.

Globally, $46 \%$ of under-five deaths occur during the neonatal period ${ }^{[2]}$, and the proportion of under- five deaths due to neonatal causes continues to rise $^{[3],[4]}$.

The common causes of neonatal mortality in India are asphyxia, prematurity and low birth weight, infections like pneumonia and gastroenteritis and a variety of surgical problems ${ }^{[5]}$.

Besides mortality, it is of fundamental importance also to analyze the determinants of morbidity in this 
group, as the early recognition and prevention of diseases contribute to reducing deaths ${ }^{[6]}$. Prematurity, LBW, infection, jaundice and asphyxia are the major morbidities affecting neonates in the developing countries which are easily preventable ${ }^{[7]}$. India has a major role to play in global efforts to decrease the preventable death of newborns and children under the age of five, given that it has the highest number of deaths among these two groups in the world ${ }^{[8]}$.

The IMR and NMR are not uniform across the country. As per a recently published report by the Sample Registration Survey (SRS) in 2017, the IMR in Assam was the second worst in the country at 44 as compared to the National average of 33 . The current NMR of India is 18 per 1000 live births in 2018 as per UNICEF data. The rate of the neonatal mortality varies widely among the different states of India, ranging from 11 per 1000 live births in Kerala to 48 per 1000 live births in Uttar Pradesh $^{[1]}$. Wide disparities are also observed in survival rates across districts within state ${ }^{[1]}$. So it is important to study the mortality and morbidity pattern of a region as it helps in implementation of new treatment protocols, interventions and planning and policy making which helps in better outcome and improvement in the quality of life among survivors.

At present there is an evident paucity of literature regarding the neonatal morbidity and mortality patterns in the neonatal intensive care units (NICU) in Assam.

A better understanding of the morbidity and mortality profile of sick newborns admitted to neonatal intensive care units will help in formulating policies for further decrease in the neonatal mortality in Assam. Hence this study was designed to explore the morbidity and mortality profile of neonates admitted to a Neonatal Intensive Care Unit (NICU) of a tertiary care teaching hospital in Silchar, Assam.

\section{Material and Methods}

This was a retrospective hospital based observational study done in the Neonatal Intensive
Care Unit (NICU) of Silchar Medical College and Hospital, Silchar, Assam.

This level III NICU serves as a referral centre for other districts of Silchar with a high percentage of referral of high risk pregnancies and sick newborns from peripheral hospitals.

Our NICU has a total of 60 radiant warmers with 45 in Inborn and 15 in Outborn unit. The neonatal unit is equipped with 20 phototherapy units, 2 bubble CPAP and 3 mechanical ventilators.

Retrospective cohort of neonates aged 0-28 days admitted to Neonatal Intensive Care Unit (NICU) during 1st January 2016 to 31st December 2018 formed the study population.

The newborns were categorised as inborn if delivered in our hospital and outborn if born outside. The key definitions used for the study are:

Preterm - live born neonate delivered before 37 weeks from $1^{\text {st }}$ day of last menstrual period(LMP) and confirmed clinically after delivery.

LBW (Low Birth Weight)- birth weight of 1500grams to 2499grams.

VLBW (Very Low Birth Weight) - birth weight of 1000 grams to 1499 grams.

ELBW (Extremely Low Birth Weight)- birth weight <1000grams.

Early Neonatal period: less than 7 days postnatal age.

Late Neonatal period: more than 7 days postnatal age.

Data collection and analysis:

The data was collected in a predesigned standardized proforma. Data from admission and discharge registers were extracted and compiled. Data on birth weight, gestational age, gender, age at admission, initial presenting symptoms at admission, final diagnosis and outcome in regards to whether the newborn was discharged after completion of treatment, left against medical advice (LAMA), referred or expired were collected. Data was analysed using appropriate statistical tools. 


\section{Results}

Table 1: The number of deliveries by NVD and LSCS and the number of live births and stillbirths.

\begin{tabular}{|l|c|c|c|c|}
\hline YEAR & 2016 & 2017 & 2018 & TOTAL \\
\hline $\begin{array}{l}\text { Total } \\
\text { deliveries }\end{array}$ & 10,070 & 10,711 & 9494 & 30,274 \\
\hline NVD & 6068 & 6674 & 5470 & 18,211 \\
\hline LSCS & 4002 & 4037 & 4024 & 12,063 \\
\hline Live birth & 9697 & 10,221 & 9046 & 28964 \\
\hline Still birth & 373 & 490 & 448 & 1311 \\
\hline
\end{tabular}

The total number of deliveries during the period from $1^{\text {st }}$ January 2016 to $31^{\text {st }}$ December 2018 was 30,274 with an average of 10,091 per year. Of this, $60.1 \%$ were NVD and $39.8 \%$ were LSCS. $4.26 \%$ were stillborn.

Table 2: Profile of babies admitted in Inborn and Outborn based on birth weight and gender.

\begin{tabular}{|c|c|c|c|c|}
\hline \multirow{2}{*}{\multicolumn{2}{|c|}{$\begin{array}{c}\text { Total } \\
\text { admission }\end{array}$}} & \multirow{3}{*}{$\begin{array}{c}\text { INBORN } \\
7053 \\
(60.51 \%) \\
3965 \\
(56.21 \%)\end{array}$} & \multirow{3}{*}{$\begin{array}{c}\text { OUTBORN } \\
4601 \\
(39.48 \%) \\
2857 \\
(62.09 \%)\end{array}$} & \multirow{3}{*}{$\begin{array}{c}\text { TOTAL } \\
11,654 \\
\begin{array}{c}6822 \\
(58.53 \%)\end{array}\end{array}$} \\
\hline & & & & \\
\hline \multirow{2}{*}{ 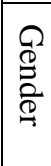 } & male & & & \\
\hline & female & $\begin{array}{c}3088 \\
(43.78 \%)\end{array}$ & $\begin{array}{c}1735 \\
(37.70 \%)\end{array}$ & $\begin{array}{c}4823 \\
(41.38 \%)\end{array}$ \\
\hline \multirow{4}{*}{ 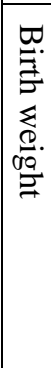 } & $>2.5 \mathrm{~kg}$ & $\begin{array}{c}3771 \\
(53.45 \%)\end{array}$ & $\begin{array}{c}2321 \\
(50.44 \%)\end{array}$ & $\begin{array}{c}6092 \\
(52.27 \%)\end{array}$ \\
\hline & $\begin{array}{c}1.5- \\
2.49 \\
\mathrm{~kg}\end{array}$ & $\begin{array}{c}2691 \\
(38.15 \%)\end{array}$ & $\begin{array}{c}1756 \\
(38.16 \%)\end{array}$ & $\begin{array}{c}4447 \\
(38.1 \%)\end{array}$ \\
\hline & $\begin{array}{c}1- \\
1.49 \mathrm{~kg}\end{array}$ & $\begin{array}{c}479 \\
(6.79 \%)\end{array}$ & $\begin{array}{c}338 \\
(7.34 \%)\end{array}$ & $\begin{array}{c}817 \\
(7.01 \%)\end{array}$ \\
\hline & $<1 \mathrm{~kg}$ & $\begin{array}{c}112 \\
(1.58 \%)\end{array}$ & $\begin{array}{c}186 \\
(4.04 \%)\end{array}$ & $\begin{array}{c}298 \\
(2.55 \%)\end{array}$ \\
\hline
\end{tabular}

There was a total of 11654 admissions during the study period of which $60.5 \%$ were in the Inborn and $39.5 \%$ were in the Outborn unit.

Male babies were predominant in both Inborn and Outborn admissions. In Inborn, the male:female ratio was 1.28 and in Outborn, it was 1.64. The overall male:female ratio was 1.41 .

Low birth weight babies $(<2.5 \mathrm{~kg})$ constituted $46.5 \%$ of total admissions in Inborn and $49.5 \%$ of total admissions in Outborn.
Table 3: Morbidity profile of babies admitted in the Inborn and Outborn units of NICU.

\begin{tabular}{|l|c|c|c|}
\hline $\begin{array}{l}\text { CAUSE OF } \\
\text { ADMISSION }\end{array}$ & $\begin{array}{c}\text { INBORN } \\
(7053)\end{array}$ & $\begin{array}{c}\text { OUTBORN } \\
(4601)\end{array}$ & $\begin{array}{c}\text { TOTAL } \\
(11,654)\end{array}$ \\
\hline RDS & $\begin{array}{c}1327 \\
(18.81 \%)\end{array}$ & $\begin{array}{c}632 \\
(13.73 \%)\end{array}$ & $\begin{array}{c}1959 \\
(16.80 \%)\end{array}$ \\
\hline MAS & $\begin{array}{c}515 \\
(7.30 \%)\end{array}$ & $\begin{array}{c}407 \\
(8.84 \%)\end{array}$ & $\begin{array}{c}922 \\
(7.91 \%)\end{array}$ \\
\hline $\begin{array}{l}\text { Other causes } \\
\text { of respiratory } \\
\text { distress }\end{array}$ & $\begin{array}{c}216 \\
(3.06 \%)\end{array}$ & $\begin{array}{c}123 \\
(2.67 \%)\end{array}$ & $\begin{array}{c}339 \\
(2.90 \%)\end{array}$ \\
\hline $\begin{array}{l}\text { Birth } \\
\text { Asphyxia }\end{array}$ & $\begin{array}{c}757 \\
(10.73 \%)\end{array}$ & $\begin{array}{c}601 \\
(13.06 \%)\end{array}$ & $\begin{array}{c}1358 \\
(11.65 \%)\end{array}$ \\
\hline Sepsis & $\begin{array}{c}1317 \\
(18.76 \%)\end{array}$ & $\begin{array}{c}1222 \\
(26.55 \%)\end{array}$ & $\begin{array}{c}2519 \\
(21.61 \%)\end{array}$ \\
\hline Jaundice & $\begin{array}{c}1556 \\
(22.06 \%)\end{array}$ & $\begin{array}{c}664 \\
(14.43 \%)\end{array}$ & $\begin{array}{c}2220 \\
(19.04 \%)\end{array}$ \\
\hline $\begin{array}{l}\text { Congenital } \\
\text { malformation }\end{array}$ & $\begin{array}{c}62 \\
(0.87 \%)\end{array}$ & $\begin{array}{c}39 \\
(0.84 \%)\end{array}$ & $\begin{array}{c}101 \\
(0.86 \%)\end{array}$ \\
\hline Others & $\begin{array}{c}1303 \\
(18.47 \%)\end{array}$ & $\begin{array}{c}913 \\
(19.84 \%)\end{array}$ & $\begin{array}{c}2246 \\
(19.27 \%)\end{array}$ \\
\hline
\end{tabular}

Morbidity profile was observed to be different in Inborn and Outborn. In Inborn, major cause of admission was Jaundice (22\%) followed by RDS $(18.8 \%)$ and Sepsis (18.6\%) and in Outborn, Sepsis $(30.09 \%)$ was the predominant cause.

Table 4: Outcome of neonates admitted in Inborn and Outborn.

\begin{tabular}{|l|c|c|c|}
\hline OUTCOME & $\begin{array}{c}\text { INBORN } \\
(7053)\end{array}$ & $\begin{array}{c}\text { OUTBORN } \\
(4601)\end{array}$ & $\begin{array}{c}\text { TOTAL } \\
(11,654)\end{array}$ \\
\hline Discharge & $\begin{array}{c}6178 \\
(87.5 \%)\end{array}$ & $\begin{array}{c}3413 \\
(74.17 \%)\end{array}$ & $\begin{array}{c}9591 \\
(82.29 \%)\end{array}$ \\
\hline Referral & $\begin{array}{c}70 \\
(0.99 \%)\end{array}$ & $\begin{array}{c}64 \\
(1.39 \%)\end{array}$ & $\begin{array}{c}134 \\
(1.14 \%)\end{array}$ \\
\hline LAMA & $\begin{array}{c}192 \\
(2.72 \%)\end{array}$ & $\begin{array}{c}295 \\
(6.41 \%)\end{array}$ & $\begin{array}{c}487 \\
(4.17 \%)\end{array}$ \\
\hline Death & $\begin{array}{c}613 \\
(8.69 \%)\end{array}$ & $\begin{array}{c}829 \\
(18.01 \%)\end{array}$ & $\begin{array}{c}1442 \\
(12.37 \%)\end{array}$ \\
\hline
\end{tabular}

The overall NICU mortality during the study period was found to be $12.37 \%$. On comparing the Inborn and Outborn mortality rates, it can be observed that the Inborn mortality $(8.69 \%)$ is lower than that of Outborn (18.01\%).

Neonates who left against medical advice (LAMA) was also found to be higher in Outborn than in Inborn. (6.41\% in Outborn and 2.72\% in Inborn). 
Table 5: Cause wise mortality data.

\begin{tabular}{|l|c|c|c|}
\hline $\begin{array}{l}\text { CAUSE OF } \\
\text { DEATH }\end{array}$ & $\begin{array}{c}\text { INBORN } \\
(613)\end{array}$ & $\begin{array}{c}\text { OUTBORN } \\
(829)\end{array}$ & $\begin{array}{c}\text { TOTAL } \\
(1442)\end{array}$ \\
\hline $\begin{array}{l}\text { Birth } \\
\text { asphyxia }\end{array}$ & $\begin{array}{c}354 \\
(57.74 \%)\end{array}$ & $\begin{array}{c}374 \\
(45.11 \%)\end{array}$ & $\begin{array}{c}728 \\
(50.48 \%)\end{array}$ \\
\hline Sepsis & $\begin{array}{c}115 \\
(18.76 \%)\end{array}$ & $\begin{array}{c}275 \\
(33.17 \%)\end{array}$ & $\begin{array}{c}390 \\
(34.15 \%)\end{array}$ \\
\hline RDS & $\begin{array}{c}69 \\
(11.25 \%)\end{array}$ & $\begin{array}{c}93 \\
(11.21 \%)\end{array}$ & $\begin{array}{c}162 \\
(11.23 \%)\end{array}$ \\
\hline MAS & $\begin{array}{c}29 \\
(3.09 \%)\end{array}$ & $\begin{array}{c}298 \\
(3.49 \%)\end{array}$ \\
\hline $\begin{array}{l}\text { Congenital } \\
\text { malformation }\end{array}$ & $\begin{array}{c}12 \\
(1.95 \%)\end{array}$ & $\begin{array}{c}111 \\
(1.32 \%)\end{array}$ & $\begin{array}{c}23 \\
(1.59 \%)\end{array}$ \\
\hline Other causes & $\begin{array}{c}44 \\
(7.17 \%)\end{array}$ & $(5.66 \%)$ & $\begin{array}{c}91 \\
(6.31 \%)\end{array}$ \\
\hline
\end{tabular}

Birth asphyxia was the major cause of death in both Inborn and Outborn babies. It was responsible for nearly half $(50.48 \%)$ of total deaths. The next leading cause was Sepsis accounting for a total of 390 deaths (34.15\%). Other causes were RDS $(11.23 \%)$, MAS (3.32\%) and congenital malformation $(1.59 \%)$.

Table 6: Age at death of babies in Inborn and Outborn

\begin{tabular}{|l|c|c|c|}
\hline $\begin{array}{l}\text { AGE AT } \\
\text { DEATH }\end{array}$ & $\begin{array}{c}\text { INBORN } \\
(613)\end{array}$ & $\begin{array}{c}\text { OUTBORN } \\
(829)\end{array}$ & $\begin{array}{l}\text { TOTAL } \\
(1442)\end{array}$ \\
\hline$<24$ hours & $\begin{array}{c}10 \\
(1.63 \%)\end{array}$ & $\begin{array}{c}29 \\
(3.49 \%)\end{array}$ & $\begin{array}{c}39 \\
(2.70 \%)\end{array}$ \\
\hline $\begin{array}{l}24 \text { hours }-7 \\
\text { days }\end{array}$ & $\begin{array}{c}548 \\
(89.39 \%)\end{array}$ & $\begin{array}{c}676 \\
(81.5 \%)\end{array}$ & $\begin{array}{c}1224 \\
(84.88 \%)\end{array}$ \\
\hline$>7$ days & $\begin{array}{c}55 \\
(8.97 \%)\end{array}$ & $\begin{array}{l}124 \\
(14.95 \%)\end{array}$ & $\begin{array}{l}179 \\
(12.41 \%)\end{array}$ \\
\hline
\end{tabular}

On analysing the age of babies at death, it was observed that majority of deaths in the NICU $(84.88 \%)$ occurred between 24 hours to 7 days age. The early neonatal death contributed to $87.5 \%$ of total deaths (558 out of 1442), whereas late neonatal death was only 55 out of 1442 , which accounted to $12.41 \%$.

\section{Discussion}

During our study period, from January 2016 to December 2018, there were a total of 11,654 admissions in NICU of which $60.51 \%$ babies were Inborn and $39.48 \%$ were outborn. The percentage of babies in Inborn and Outborn is comparable to that of other studies done by Kumar R et al, Sharma A K et al and Malik et $\mathrm{al}^{[9],[10],[11]}$. There was male predominance with respect to NICU admissions. Similar finding with respect to the gender distribution was reported by several studies $^{[11],[12],[13],[14],[15],[16]}$. Also, the male:female ratio was higher in Outborn than Inborn. Gender bias as a cause for higher number of male admissions in Outborn needs to be further evaluated However, it is also possible that the true rate of illness was lower in female neonates. Low birth weight constituted $47.7 \%$ of total admissions in our NICU, which was slightly higher than that observed in their studies by Sridhar R et $\mathrm{al}^{[17]}$, Baruah et $\mathrm{al}^{[15]}$, and lower than that obtained by Malik $\mathrm{S}$ et $\mathrm{al}^{[11]}$ and Niru Prabha Saharia et al ${ }^{[17]}$.

On analysis of morbidity profile of admitted neonates, the major causes of admission to NICU were found to be jaundice, RDS, sepsis, Birth asphyxia and MAS. Morbidity profile was similar to that obtained in their studies by Kumar $\mathrm{R}$ et $\mathrm{al}^{[9]}$, Baruah et $\mathrm{al}^{[15]}$, Malik S et al ${ }^{[11]}$, Sharma AK et al ${ }^{[10]}$ and Kannan $R$ et $\mathrm{al}^{[18]}$.

Out of the total 11,654 admitted neonates, 134 were referred to other centers and 487 left against medical advice (LAMA). Out of the remaining 11,033 neonates $9591(82.29 \%)$ were discharged successfully and 1442 (12.37\%) expired.

Mortality rate in our NICU( $12.37 \%$ ) was similar to that obtained in their study by Kumar $\mathrm{R}$ et $\mathrm{al}^{[9]}$ $(11.41 \%)$ and Niru Prabha Saharia et $\mathrm{al}^{[17]}(13 \%)$. Mortality rate reported varies among different studies from different parts of the country. Mortality rate was $20.53 \%$ in a study by Rakholia $\mathrm{R}$ et $\mathrm{al}^{[19]}$, Baruah et $\mathrm{al}^{[15]}(10.2 \%)$, Sridhar PV et $\mathrm{al}^{[20]}(7.16 \%)$.

The mortality data shows much higher mortality in outborn (18.01\%) compared to inborn $(8.69 \%)$. Studies by Kannan $\mathrm{R}$ et $\mathrm{al}^{[18]}$, Baruah et $\mathrm{al}^{[15]}$ and Panda et $\mathrm{al}^{[21]}$ also shows higher mortality in outborn neonates. The higher outborn mortality may be due to issues like inadequate functioning of peripheral neonatal facilities like NBSUs, delayed referral, lack of pre-transport stabilisation.

In our NICU, $87.5 \%$ deaths occurred within the first seven days of life. This is in concordance with the findings by Malik $S$ et $\mathrm{al}^{[11]}$ and Baruah et $\mathrm{al}^{[15]}$. 
Majority of deaths in the Early neonatal period emphasises on the importance of care during immediate postnatal period.

On analysing the major causes of neonatal death in our NICU, we observed that birth asphyxia contributed to $57.74 \%$ deaths in Inborn unit and $45.11 \%$ deaths in Outborn unit. Asphyxia was the leading cause in other studies done by Sridhar PV et $\mathrm{al}^{[20]}$, kailash Chandra et $\mathrm{al}^{[22]}$ and Niru Prabha Saharia et $\mathrm{al}^{[17]}$. This high number of deaths due to asphyxia may be caused by poor obstetric care at the peripheries and late referral of mother. Other causes of mortality in our NICU were sepsis, RDS, and MAS.

\section{Limitations of the Study}

This study has some limitations, as this was a hospital based retrospective study, the cause of death was determined using the data available in case record sheets. As the majority of the patients presenting to us belong to low socio-economic status, the results from this study cannot be a complete reflection of the problem in the community as a whole. Multicentre, prospective studies including major centers providing neonatal care in the region are needed.

\section{Conclusion}

Data pertaining to disease pattern and mortality are useful for health care providers and policy makers to modify and plan treatment or interventions and evaluate the effectiveness of health care initiatives respectively. This study analyzed the morbidity and mortality profile of neonates admitted to Neonatal Intensive Care Unit (NICU) of a tertiary care teaching hospital in Silchar, Assam.

From our study, we could conclude that jaundice, sepsis, RDS and birth asphyxia are the leading cause of admission in our NICU. The findings of the study highlight that major contributors to the neonatal mortality in our setup are Birth asphyxia, sepsis and RDS.

Improving the antenatal care, maternal health and timely intervention by referral to tertiary centers will help improve neonatal outcome.

\section{References}

1. State of newborn health in India. Journal of Perinatology (2016) 36, S3-S8

2. WHO Global Health Observatory Data Repository, Available at http://www.who.int/gho/database/en/(Access ed : $10^{\text {th }}$ November 2019.

3. Bhutta ZA, Das JK, Bahl R, Lawn JE, Salam RA, Paul VK, et al. Can available interventions end preventable deaths in mothers, newborn babies, and stillbirths, and at what cost? Lancet. 2014;384:347-70. Medline: 24853604 doi:10.1016/S0140-6736 (14)60792-3

4. Liu L, Oza S, Hogan D, Perin J, Rudan I, Lawn JE et al. Global, regional, and national causes of child mortality in 2000-13, with projections to inform post-2015 priorities: an updated systematic analysis. Lancet 2015; 385(9966): $\quad 430-440 . M e d l i n e: 25280870$ doi:10.1016/S0140-6736(14)61698-6)

5. Jain S, Bhakoo ON, Singh M (1990) Neonatal Monitoring, Recommendations and Proceedings of theSeminar 1990. Chathram Hospital \& Research Centre. Indore, pp: 617

6. Martins Christine, Barcelon Ariane, Lima Fernanda, Gaíva Maria.(2014). 'Profile of Morbidity and Mortality in at risk Newborns'. Cogitare Enfermagem.19.109115 .

7. Chan MCK. 'Specific problems in developing countries'. In: Rennie JM, Roberton NRC (editors). Textbook of Neonatology. (3rd edition. Edinburgh: Churchill Livingtone 2000); 111-18

8. Bora JK, Saikia N.(2018) 'Neonatal and under-five mortality rate in Indian districts with reference to Sustainable Development Goal 3: An analysis of the National Family Health Survey of India (NFHS), 20152016.PLOS ONE 13(7): e0201125.

9. Kumar R, Mundhra R, Jain A, Jain S. 'Morbidity and mortality profile of neonates admitted in special newborn care unit of a 
teaching hospital in Uttarakhand, India'. Int J Res Med Sci(2019);7:241-6

10. Sharma AK, Gaur A. 'Profile of neonatal mortality in special newborn care unit of tertiary care hospital'. Int J Contemp Pediatr(2019);6

11. Malik S, Gohiya P, Khan IA. 'Morbidity profile and mortality of neonates admitted in Neonatal Intensive Care Unit of a Central India Teaching Institute: A prospective observational study'. J ClinNeonatol (2016); 5:168-73.

12. Modi R, Modi B, Patl JK, Punitha KM. 'Study of the Morbidity and the Mortality Pattern in the Nonatal Intensive Care Unit at a Tertiary Care teaching Hospital in Gandhinagar District, Gujarat, India'. J Res Med Den Sci 3:208-(2015);12. DOI: 10.5455/jrmds.20153311

13. Kumar MK, Thakur SN, Singh BB. 'Study of the Morbidity and the Mortality Patterns in the Neonatal Intensive Care Unit at a Tertiary Care Teaching Hospital in Rohtas District, Bihar, India'. J Clin Diagn Res (2012);6:282-5. DOI: JCDR/3687:1994

14. Harsha PJ, Iyer CR, Rathod AD, Nagendra K, Chandan CK, Gornale VK. 'A Prospective observational study of short term morbidity pattern in preterm newborns delivered in a tertiary care hospital'. J Evidence based Med Healthcare (2015); 2:5432-37. DOI: 10.18410/ jebmh/2015/755

15. Baruah MN, Panyang PP. 'Morbidity and Mortality Profi le of Newborns Admitted to the Special Care Newborn Unit ( SCNU ) of A Teaching Hospital of Upper Assam, India - A Three Year Study'. J Med SciClin Res (2016);4:11689-95. DOI: 10.18535/jmscr

16. Sonia Bhatt, Abhishek Singh, Shewtank Goel, Anil Kumar Goel. 'An Evaluation of mortality pattern in the Neonatal Intensive Unit of a tertiary care centre from Western Uttar Pradesh'. Sch. J. App. Med. Sci., June (2016); 4(6E):2224-2228
17. Niru Prabha Saharia, Arati Deka, Vivekananda M.S 'Mortality and Morbidity Pattern of Neonatal ICU of Gauhati Medical College and Hospital'. IOSR Journal of Dental and Medical Sciences(2016) vol 15, issue 6, PP 73-75.

18. Kannan R, Rao S, Mithra P, Rajesh SM, Unnikrishnana B, Rekha T. 'Neonatal Mortality and Morbidity in a Tertiary Care Hospital of Coastal South India'. J Nepal Paediatr Soc(2017);37(3):232-237

19. Rakholia R, Rawat V, Bano M, Singh G. 'Neonatal morbidity and mortality of sick newborns admitted in a teaching hospital of Uttarakhand'. CHRISMED J Health Res. (2014) Oct 1;1(4):22

20. Sridhar PV, Thammanna PS, Sandeep M. 'Morbidity Pattern and Hospital Outcome of Neonates Admitted in a Tertiary Care Teaching Hospital, Mandya'. Int J Sci Stud(2015);3(6):126-129.

21. Panda S. Mortality \& morbidity profi le in vlbw \& elbw neonates admitted to NICU in HMCH. Yuva J Med Sci(2016);1:51-5.

22. Aggarwal KC, Gupta R, Sharma S, Sehgal R, Roy MP. Mortality in newborns referred to tertiary hospital: Anintrospection. $J$ Family Med Prim Care.(2015);4(3):435438. 